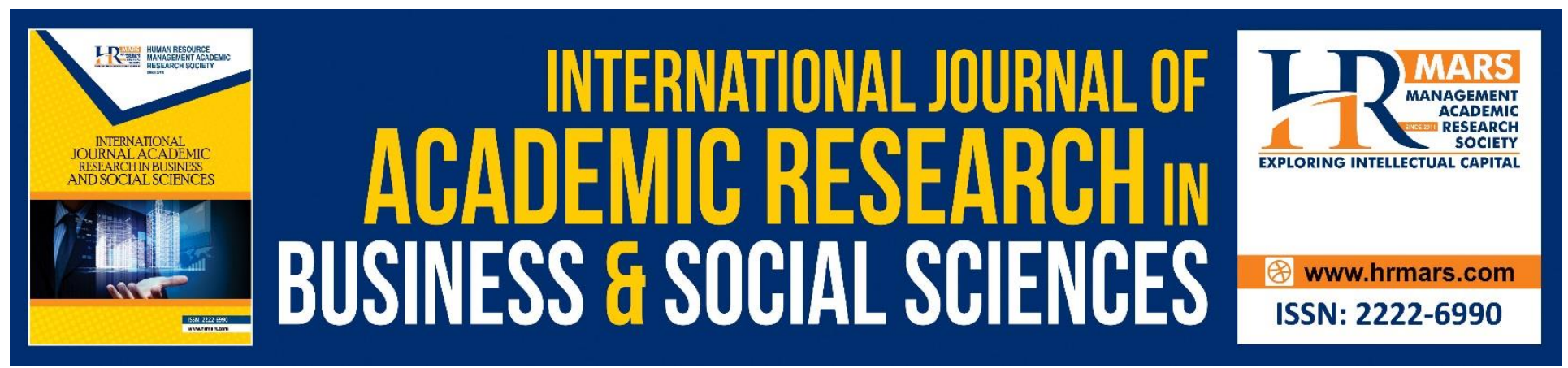

\title{
Corporate Governance Practices and Capital Structure: Evidence from Malaysian Capital Market
}

\author{
Nazaria Binti Md. Aris, Suzila Binti Mohamed Yusof, Kerk Yee Xuan, Nurul \\ Syuhada Binti Zaidi, Ahmad Syubaili Bin Mohamed
}

To Link this Article: http://dx.doi.org/10.6007/IJARBSS/v11-i14/8530

DOI:10.6007/IJARBSS/v11-i14/8530

Received: 30 November 2020, Revised: 28 December 2020, Accepted: 10 January 2021

Published Online: 27 January 2021

In-Text Citation: (Md. Aris, 2021)

To Cite this Article: Md. Aris, N. B., Yusof, S. B. M., Xuan, K. Y., Zaidi, N. S. B., \& Mohamed, A. S. B. (2021). Corporate Governance Practices and Capital Structure: Evidence from Malaysian Capital Market. International Journal of Academic Research in Busines and Social Sciences. 11(14), 71-94.

Copyright: () 2021 The Author(s)

Published by Human Resource Management Academic Research Society (www.hrmars.com)

This article is published under the Creative Commons Attribution (CC BY 4.0) license. Anyone may reproduce, distribute, translate and create derivative works of this article (for both commercial and non-commercial purposes), subject to full attribution to the original publication and authors. The full terms of this license may be seen

at: http://creativecommons.org/licences/by/4.0/legalcode

Special Issue: Contemporary Business and Humanities Landscape Towards Sustainability, 2021, Pg. 71 - 94

http://hrmars.com/index.php/pages/detail/IJARBSS

JOURNAL HOMEPAGE

Full Terms \& Conditions of access and use can be found at http://hrmars.com/index.php/pages/detail/publication-ethics 


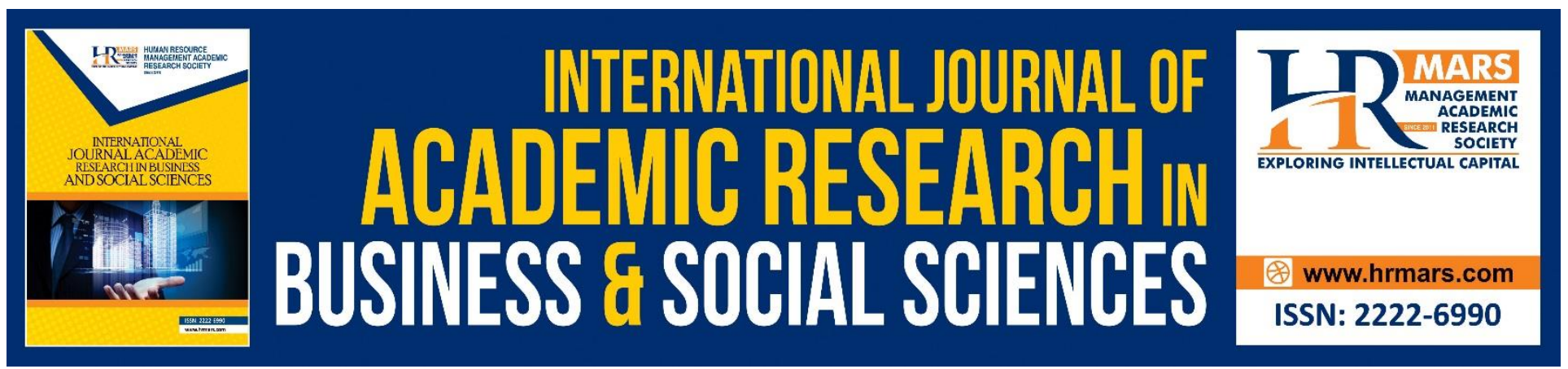

\title{
Corporate Governance Practices and Capital Structure: Evidence from Malaysian Capital Market
}

\author{
Nazaria Binti Md. Aris, Suzila Binti Mohamed Yusof, Kerk Yee Xuan, \\ Nurul Syuhada Binti Zaidi, Ahmad Syubaili Bin Mohamed \\ Faculty of Economics and Business, Universiti Malaysia Sarawak, Kota Samarahan, Sarawak
} Email: manazaria@unimas.my

\begin{abstract}
s
Corporate Governance has become the most inevitable issues around the world as the emergence of prominent corporate scandals, for example, Enron and WorldCom. It was also known as an important key of leading good financing decision in a company. The motivation behind this project sought to investigate the influences of the Corporate Governance practices on capital structure decision among Top 100 companies for overall Corporate Governance and performance in Malaysian Capital Market over the period 2012 to 2016. All data was gathered from annual report of Malaysian listed firms in Bursa Malaysia Stock Exchange, excluding the financial companies due to their special rules and regulation in their Corporate Governance system. This study has been employed descriptive analysis, correlation analysis and fixed effects regression model to find out the research objectives. Results from the research indicate that board gender, independence audit committee, and profitability were statistically negative to leverage. Further, the research also found that large firm size with high managerial ownership will pursue high debt policy. Nonetheless, debt- to-equity ratio has no zero relationship with board size and board independence. These findings will be useful to the policymaker to formulate Corporate Governance mechanisms as well as investors for assessing the listed companies in Malaysia before making investment decision.
\end{abstract} Keywords: Corporate Governance, Capital Structure Decision, Non-financial Listed Malaysian Companies

\section{Introduction}

In Malaysia, Norwani et al (2011) stated that the Bumiputera Malaysia Finance scandal, the Perwaja fiasco, the corporate malfeasance of Technology Resources Industries (TRI) Berhad, and extensive problem of Malaysian Airline System (MAS) caused regime of Malaysia to reinforce the framework of Corporate Governance system. Weaknesses of Corporate Governance Malaysia has been highlighted and required to rectify and renovate. According to Heng et al., (2012), Malaysia has experienced well performance and become one of the rapid developing countries as well as able to 
fight against the global market after Corporate Governance reforms. Bursa Malaysia Stock Exchange market has applied the concept of Corporate Governance actively because it will grant a positive influence on sustainable economic growth in Malaysia. As an evidence, MSWG (2016) said that Transparency Index for the Top 100 Companies in the MSWG-ASEAN CG Scorecard evaluation had an upward trend since 2012 which rose from 68.20 points in 2012 to 85.02 points in 2016 with assessment of 868 Malaysian companies, it indicated increasing of firm's disclosures and Corporate Governance practices in Malaysia.

Also, this assessment has involved almost 900 Malaysian companies in 2017. Good Corporate Governance practice brings a lot of benefits to a firm. For instances, influence strategic decisions of a company significantly such as the financial leverage decision that are made by the board directors, as well as the financial health of a firm will be affected (Waworuntu et al., 2014). Also, building of confidence among investors and lenders. Abor (2007) state that stakeholders and the communities are required more transparent in their dealings as well as disclose more relevant information so that they can justify their investments and financing decisions. Therefore, Heng et al., said that the issue of capital structure decision should take in consideration since it will affect the cost of financing and growth of a particular company and consequently influence firm performance. Such issue should be aware regarding the Corporate Governance policy.

In addition, variable of board of directors is the primary component in the Corporate Governance practices to evaluate the relationship with companies' financial leverage decision. The breach between managers and shareholder as well as agency issues always be the problem in this subject area. Hence, it can be confirmed that board directors have a relationship with companies' capital structure. Moreover, another two factors of Corporate Governance which are board of gender and independence of audit committee that have been strengthen in Code of Malaysia recently. Again, it can be obviously seen that there are limited studies have concerned about this in other countries even in Malaysia. This maybe the research gap through examining such relationship. Such appropriate combination of financing plays a vital element of a firms' value as well as avoid financial distress occur even lead the company to bankruptcy (Modugu, 2013).

Therefore, the levels of debt and equity financing used will follow the guidance of adoption of appropriate Corporate Governance. Abor (2007) said that a firm with sound Corporate Governance will having a good decision in financing, direct the firm to have a better performance in overall, sometimes it will extent to working capital management level and dividend policy.

\section{Literature Review and Hypothesis}

Corporate Governance Framework

Cadbury (1992) defined a company was well directed and monitored through Corporate Governance system. It is about the board of directors who are designated by shareholder ought to take the responsibility to lead the company, maximize the shareholder value and also protect the interest of stakeholder. In short, directing means to guide the company to achieve the goals successfully with making the decision wisely while monitoring means to monitor the management of company with providing framework of control mechanisms for getting the best result and performance. 
Another definition of Corporate Governance was defined as the relative power of managers, shareholders, owners have practiced in several methods globally. This means that the way of firms is monitored, directed, controlled can be affected by different aspects such as laws, policies, rules, regulations and customs. Such Corporate Governance practices are vital to assure the accountability and clarity of disclosure by the firms as well as limit the contention between principal and agent (Okiro et al., 2015).

Malaysian Code on Corporate Governance (MCCG) (2017) declared that Corporate Governance was characterised as the procedure and structure used to coordinate and deal with the business and issues of the companies toward promoting success and corporate responsibility. The prosperity of a company depends on how well the Corporate Governance applied, how well the relationship between manager, shareholder and stakeholder. Good governance will bring the prosperity and increment the firm value.

Corporate Governance consists of internal mechanisms (managerial ownership, foreign ownership, board composition, governmental ownership, state ownership or other institutional ownership) and external mechanism (statutory audit, stock market assessment of corporate performance and market for corporate control) which act as an agenda for effective nursing, directing and controlling of corporate (Okiro et al., 2015). There are few Corporate Governance mechanisms which has proposed by the Malaysian governance reform agenda and required to apply in the Malaysian corporate sectors. Singam (2003) pointed out the mechanism include ownership structure, board structure (CEO duality, independence of board, board size, and professionalism), board activity (board committee and board meeting), remuneration, transparency and disclosure as well as mergers.

Abor (2007) declared that sound Corporate Governance will build a trust among the investors. This is because a sound of Corporate Governance will generate the confidence as well as goodwill of investors as assuring that their capital will get back and their investment will get an adequate return. Again, Okiro et al., (2015) said that the great Corporate Governance is investors friendly due to their high creditworthiness, transparency as well as disclosures in all information.

Agyei \& Owusu (2014) identified that better Corporate Governance will alter the strategic decision of a company include cost of financing, valuation, expansion of business as well as management system. If a company with a poor Corporate Governance will cause the lender refuse to lend due to the safety of loan and high possibility to default and hence affecting the capital structure. Since the external financing is in trouble, the firm will entirely rely on the internal financing to sustain the ongoing operations and investment plans. As a result, the possibilities of financial distress are more likely to occur at individual firm due to the unbalance of financing problem as well as spread to other corporates, consumer and employees.

\section{Theoretical Capital Structure}

Capital structure choice is significant in driving the firm from having good financial health (Waworuntu, 2014). An optimal financial selection assures the firm maximize the shareholder's 
wealth as well as the organization work more efficiently. Nevertheless, Myers (2001) disputed that there is no all-inclusive hypothesis to determine the optimal financial leverage decision. Management will consider several of factors such as the characteristics of company, motive as well as the objectives of the managers to value the costs and benefits and then to decide their financing decision which can maximize the value of corporates (Modugu, 2013).

In light of the contextual analysis by Modigliani and Miller (M\&M), using the debt financing has tax advantages and consequently increase the value of company. Basically, pure theory tends to use all debt capital structure, but that is an extreme case (Waworuntu et al., 2014). Apart from that, the bankruptcy cost will increase when employing more debt as three theories (Trade-Off Theory, Pecking Order Theory and Agency Theory) have been recommended by Modigliani and Miller (MM) to explain on debt - equity framework.

\section{Track-Off Theory}

There are numbers of capital structure theories in the world such as Agency Theory, Free Cash Flow Theory, Market Timing Theory and Signaling Theory. However, the most acceptable of theories on capital structure are Trade-Off Theory, Pecking Order Theory as well as Agency Theory (Mostafa and Boregowda, 2014). Trade-Off approach can be known as the earliest capital structure theory which is originated from the study by Kraus and Litzenberger (1973) and is emphasized on every firm have their optimal capital structure.

Myers (2001) declared the level of marginal value of tax shields which can entirely offset the financing costs is a way to decide the level of debt that a company will borrow. Basically, such theory is the tradeoff connecting the advantages gained (Interest Tax Shields) and the losses (Cost of Financial Distress, Agency costs, Bankruptcy costs) incurred to define best level in capital structure decision.

In an ideal capital structure, costs of financial distress are eliminated by the tax advantages completely. According to Farooq et al., (2012), financial distress can be assigned to the Bankruptcy costs and Agency costs emerged from the creditworthiness of a firm is default. Such financial distress is a costly process and will cause a negative impact on the financing decision as well as firm performance.

The bankruptcy costs can be either direct costs (legal and administrative expenses) that incurred by a firm when the firm is default or the costs associated with the insolvency whereas indirect costs comprise of loss of sales and profit, decrease creditworthiness and the reduction of market value of the firms due to unable to pay off the debt when it comes to due such as opportunity losses, cost of suppliers, cost of customer and so on (Fama \& French, 2002). Studies have shown that Myers (2001) emphasized that the trade-off theory justified optimal debt levels and identified that ideal debt ratios are different among the companies. He said safety corporates with tangible assets and high profitability tend to borrow more due to the lower default risk. Unprofitable companies with risky, intangible assets (sustain damage if financial distress in encountered) are more prefer on equity financing. 
This theory has aligned with the study by Ruan et al., (2011) which is managerial shareholding affects the firm's leverage decision significantly. They declared that managers might tempted the interest tax shields of debt financing and use the debt intensively at the expense of shareholders when the managerial shareholding is lower. Otherwise, managers will use less debt as the risk of bankruptcy when the managerial ownership is high as well as their interests are aligned with shareholders.

\section{Pecking Order Theory}

Theory of the Pecking Order was suggested by Myers \& Majluf (1984). Such theory did not focus on ideal level of debt financing. As an alternative, it occurs due to the presence of asymmetric information on the financial market as well as conflict between insider and outsider which affects the firm's sources of financing either internal or external as well as between financing selection between debt or equity securities (Brealey et al, 2014). Such asymmetry will disrupt the value of the company, in case improperly evaluate the new project when they decide to issue new shares (Rodrigues et al., 2017).

Based on the study of Myers (2001), debt issues will minimize the information advantages of the corporate managers. When the shares of the firm are undervalued, the financing managers will issue debt in contrast they will issue shares when overpriced. It also can be said that the equity issuance exists when the debt issuance is costly. The asymmetric information will be resolved while retained earnings are used instead of issue new equity (Chen et al, 2011).

Apparently, equity financing is costly as compared to debt borrowing since there an arising of asymmetry information between insider and outsider. Although the managers can choose to issue equity but the pecking order implies that manager will comply with the pecking order theory, from the safety way to riskier. Firstly, managers will select internal finance such as retained earnings before sto external finance. Due to some extreme situations, firms will use the external funds, but debt financing will be the first choice, then convertible securities will be the next and lastly is the equity issuance (Myers, 1984). Myers (2001) revealed that such theory clarifies the reason for firms with high profitability were less rely on debt financing due to these firms had more internal financing available for capital investments instead of they had a low target in debt ratio. While, firms with low profitability will apply the pecking order theory by issuing more debt when insufficient of internal funds provided. Moreover, the proposed of this theory also supported by the studies of Chen et al., (2011), Fama \& French (2002) and Agyei \& Owusu (2014). They realized a negative correlation between profitability and financing decision which is align with such theory. Seemingly, these findings have shown that company's profitability affect the leverage decision.

\section{Agency Theory}

Agency Theory was founded by Jensen \& Meckling in year 1976 and noted that this theory can be defined as the interaction between principals and agents in a common business. This relationship occurs when the owners of the firm are not the one to manage or direct their firms personally. The 
managers (agents) which act on the behalf of shareholders, owners (principals) have been delegated with some authorities to manage and make decisions for the firm. However, such decisions can be made depend on the interest of shareholders or contrary to benefit of shareholders. When the decision of manager is not aligned with the interest of shareholders, this will result agency problem (Okiro et al., 2015).

Agency problem exists as the breach of ownership and control in the corporate (Fama \& Jensen, 1983). Again, it can be arising when the existing of asymmetric information as the agents know more information and condition of the firm than the shareholders, hence abuse their authorities. Then, there will be a cost occurred in agency problem known as agency cost. Such costs include bonding cost, monitoring cost and residual loss. Because of the agency problem, the ideal financing decision is needed to find out the equilibrium of utilization of debt with equity as long as firms' value is maximized (Waworuntu et al, 2014).

Moreover, Ghazouani (2013) pointed out that agency cost will occurs from the disputes between shareholders and managers due to the manager's interest are not align with the benefits of shareholders, managers tend to pursue the gains of the companies to manage their benefits at the expense of the shareholders. For instances, shareholders tend to focus on investment for increasing their shareholder values while managements more prefer to maximize their personal wealth in expansion of the businesses. Purag et al, (2016) stated that such behaviour of the managers who concentrate on own interests instead of maximizing the interest of shareholders is known as moral hazard.

The second form of dispute is that of shareholders with creditors. Shareholders may prefer the investment of risky project that can gain higher returns when the project is succeed but it is not along with the interest of bondholders as they will only suffer the loss when the investment is failed and the shareholders have the right to walk away (Myers, 2001). Besides, the Agency Cost of equity could be controlled by using the debt financing as higher debt will reduce the sale to equity as well as excessive debt will reduce the manager's privilege to expense at the shareholder (Jensen \& Meckling, 1976).

To eliminate the agency cost, the managerial shareholding should be increase as the interest between shareholders and managers will hence increase and could cause the borrowings of firm's increase (Jensen, 1986). But, this has contrary with trade-off theory. managers will use less debt as the risk of bankruptcy when the managerial ownership is high. Agency Theory is one of the theories gaining solid empirical backing to explain the capital structure decision. Based on the Jensen and Meckling (1976), the correlation between the principals and agents involves delivering of decision making power to the agent which given by the principal. Also, Agyei and Owusu (2014) proposed that Agency Theory is the most important theory for analysing the relation between Corporate Governance and financing decision. The variables of board size, board independence, managerial ownership have been used in this research. To prove it, number of past researches have been done by researchers to inspect the effects of Corporate Governance on corporate leverage decisions. 
According to the Agency Theory, Kajananthan (2012) submitted that board independence is positively correlated with a decision on the financial leverage. He demonstrated that supervisory performance of board independence director highly reduces the conflict between shareholders and companies' directors. Therefore, corporates were being controlled effectively will create higher creditworthiness of firm, result more debt can be borrowed. The result is similar with the findings by Abor (2007) as well as Siromi and Chandrapala (2017) which indicated positive linkage between firms' outside directors and capital structure.

\section{Conceptual Framework}

Figure 1 indicates the independent variables in this study are board gender (BG), board independence (BI), board size (BS), managerial ownership structure (MG) and independence of audit committee (AC) while the dependent variable is total debt ratio i.e. a proxy for capital structure. Firms size and profitability are the control variables in this study.

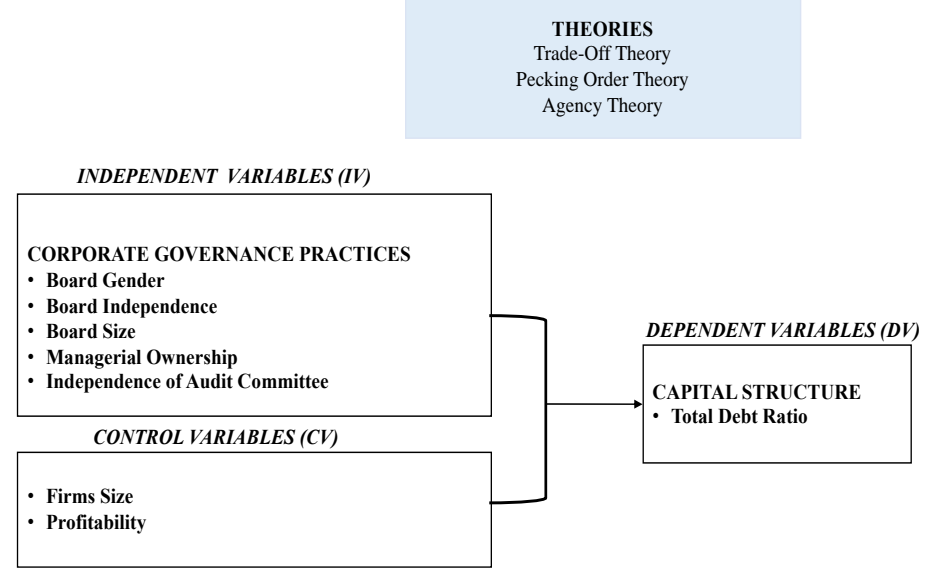

Figure 1: Conceptual Framework

In recent year, most of the countries have concerned about the gender diversity in board and listing several requirements to maintain the ratio of board gender (Jaradat, 2015). Based on the Deloitte Touche Tohmatsu India (2015), it stated that Corporate Governance in India required not less than one woman directors on board for the public listed companies. In Europe, the European Commission has proposed legislation would comprise $40 \%$ female on board by 2020 . In France, parliament announced that public companies who are employing more than 500 workers should have $40 \%$ quota for women board representation by 2017 . The necessity of having board gender diversity has been strengthening by Malaysian government regularly. Securities Commissions (2017) identified that the new MCCG 2017 highlights the Large companies need to impose about not less than $30 \%$ of women directors and also promotes participation of women in senior management.

There are many theories that support for board diversity. According to agency theory, Carter et al., (2003) have suggested that more distinct board in a company will bring more advantages. Furthermore, resources dependent theory reported that board diversity has the potential to obtain other essential resources due to the different gender has the power to create different information for a better decision making. Jaradat (2015) discovered board gender has significant affect the 
firm's capital structure decision positively and declared that diverse board acquires more resources and unique information. Another study by Rovers (2013) found that women on board will increase the efficiency on work and also the firm performance. The hypothesis can be developed as follows from the previous discussion:

\section{$H_{1}$ : There is a significant relationship between board gender and the capital structure.}

Zabri et al., (2016) described board independence as non-executive director who are free from any businesses to exercise their personal judgement as well as the ability to consider the goals and objectives of an organization. Based on the agency theory, the independent outside executive means that the director has no associate with the firm. As a result, their effort and diverse perspectives will towards the benefits of the company and reduce the dispute between managers and shareholders. According to Deloitte Touche Tohmatsu India (2015), for all listed companies in Asia, at least one-third of board independence is required, while in the United States, the Council of Institutional Investors (CII) and Corporate Governance policies state that at least two-thirds of independent directors are needed. In Malaysia, MCCG 2017 asserted that independent directors in listed firms need to comprise at least $50 \%$ at the board. Abor (2007) have conducted the study of Corporate Governance attributes and financial leverage decision in Ghanaian listed firms. The verified result is a significant positive association between the proportion of external directors and the decision on a financial leverage. He found that existence of outside directors will help the firm to attract more external resources from the lenders due to indicate that the firm is being controlled. Board independence provide useful information and knowledge to lead the company. The sign of the outcome is similar to the study of Kajananthan (2012) also presented that board with more outside directors performed better than other firms. In addition, Siromi and Chandrapala reported that the variable of board composition is significant influence the financial decisions positively. Conversely, Achchuthan et al., (2013) have concluded that there is zero relation between board independence and leverage decision by firms. But, some researchers found that independence of board director has a negative influence on leverage ratio (Adegbile, 2015; Uwuigbe, 2014). In order to test the results of the previous study, the hypothesis is as follows:

\section{$\mathrm{H}_{2}$ : There is a significant relationship between board independence and the capital structure.}

MCCG stated that board should examine its size in order to determine the impact of the number upon its effectiveness. The optimal board size of the firm is from 6 to 7 members according to the Corporate Governance Blueprint 2011. The directors play a vital role in managing the firm with making number of strategic decision every day especially in financial mixed. According to Zabri et al., (2016), the board size was depended on the circumstances or environments changed and desires of the company in term of size, scope or geography; the executive or non-executive directors and outside director need to be balanced for creating higher efficiency in its roles and responsibilities. Therefore, a success organization should consist of effective and optimal size of board to direct the company and finally maximize shareholder wealth. Some of preceding empirical researches revealed 
the interaction between Corporate Governance practices that influence the financing decision. Abor (2007) said the listed Ghanaian firm pursues high debt policy with a larger board size and concluded that average board size is 9 with non-executive directors representing 73 percent of board members. The results are consistent with discoveries by Agyei and Owusu (2014), they displayed there is a positive relationship between board size and financing decision for Ghanaian listed manufacturing firm by using multivariate regression analysis. While, Jadarat (2015) identified the correlation between firms' Corporate Governance practices and financial leverage decision in Jordanian corporates by using OLS and multiple regression. The study disputed the board size influences the leverage positively in order to decrease the agency cost. In contrast, a case by Vakilifard et al., (2011) displayed that firm's board size of firm was negatively correlated with the capital structure decision. They mentioned that the bigger size of board will have a better Corporate Governance and hence lead to low debt expenses. Besides that, the result was similar to the Adegbile (2015) and Uwuigbe (2014). Conversely, Zabri et al., (2016) inspected the linkage between Corporate Governance and leverage by using descriptive as well as correlation analysis. The result proved that there is insignificant relationship between them. In that regard, the following is stated as:

\section{$H_{3}: \quad$ There is a significant relationship between board size and the capital structure.}

Managerial ownership has been described as separating ownership and control in public corporations to establish a possible conflict of interest between managers and shareholders. According to Ruan et al., (2011), the connection between the interests of managers-shareholders become stronger because of increase in managerial ownership. This lead to better control and even increase firms' value. They found that the interests of manager are fully align with the interests of shareholders when the managerial ownership reaches a higher level and the agency problem can be largely eliminated. This statement has aligned with the study by Jensen and Meckling (1976), there is a conflict between agency because of the breach of ownership and control and it can be resolved when the level of managerial ownership increases cumulatively. Based on the agency theory, Jensen (1986) argued that the conflict between managers -shareholders would be reduced by an increase in managerial ownership and could lead to an increase in debt borrowing. It means there is a positive relation. Also, managerial ownership significantly influences financing decision positively which is similar with Corporate Governance philosophy according to Agyei and Owusu (2014).

Nonetheless, there was an opposite side has been noted. When the managers hold large proportion of share, the agency conflicts with shareholders will reduce, resulting in decreasing the debt level and the risk of bankruptcy. Berger et al., (1997) define managers will minimize the utilization of debts to achieve the better performance of firm and hence maximize the wealth of shareholder as well as debt financing are substituted through managerial ownership. It thus shows a reversal of the relationship between the management shareholding and the financing decision of the firm. There is mixed evidence of correlation between the management shareholding and the firm's decision on the capital structure. A finding by Uwuigbe (2014) also along with the finding of Berger et al., (1997) where managerial ownership has a negative influence on financing decision among Nigerian listed firms. He defined that managers will became risk-averse as well as refuse to adopt more debt due to 
the default of risks when the level of managerial ownership increases. Nonetheless, Siromi and Chandrapala (2017) used multiple regression analysis to analyse the effect of Corporate Governance on the financial leverage decision of listed firms in Sri Lanka. The study reported managerial ownership is insignificant with debt-equity choice. Such findings also provide the same result with the study by Waworunto et al., (2014) insignificant between management shareholding and the financing decision of the firm. Thus, the below hypothesis can be created as:

\section{$H_{4}$ : There is a significant relationship between managerial ownership and the capital structure.}

According to MCCG, 2017, strengthen of the Audit Committee is one of the highlight issues and it has not been paid attention before that. Also, none of the relevant study has investigate this Corporate Governance variables in Malaysia. Hence, it might be one of the important research gaps in this study. MCCG, 2017 reported that the Chairman of the Audit Committee shall not be the Chairman of the Board and the Committee shall consist exclusively of independent Directors. The Audit Committee plays a key role in a Corporate Governance system, which also involves the company's financial and audit issues. This will add accountability, attention and critical judgment to the process of financial reporting, as well as protect shareholder interests. Based on Waworuntu et al., (2012), the better the quality of audit committee, the better the Corporate Governance becomes and hence the lower debt will be when the Corporate Governance is enhanced. A finding by Ali and Ahmed (2015) revealed that the audit committee independence has affect the debt ratio positively. The independence of audit committee can well mitigate the agency problem between management and shareholders. Such result inconsistent with outcomes by Arslan et al., (2014) and Muazeib et al., (2015) where independent of audit committee will result smaller cost of debt. Muazeib et al., (2015) said that there is arising of agency cost in inherent moral hazard among the principal-agent relations. Such situation is aligned to the agency theory. For instances, the agent will consider own interest to adopt accounting procedures that create favourable accounting results. An effective audit committee will try to reduce this illegal actions and incentive problems. This strengthens the consistency and integrity of the annual audited financial statements, preserving and safeguarding shareholder interests. The higher audit committee independence has result lower chance of frauds (Muazeib et al., 2015). Therefore, they found that higher independence of audit committee plays crucial role to improve performance of companies. Based on the arguments, this research considers this hypothesis as following:

H5: There is a significant relationship between the independence of audit committee and the capital structure.

\section{Data Analysis}

Sample Description and Data Collection

In this project, type of data involved is the secondary data which was gathered from annual report of Malaysian firms in Bursa Malaysia Stock Exchange with fulfil the condition of Top 100 Companies for Overall Corporate Governance and Performance over the period 2012 to 2016. The annual report includes financial reports i.e. Income Statement, Statement of Financial Position, Statement 
of Cash Flows and Statement of Changes in Equity and non-financial report i.e. Corporate Governance Report. Apart from that, several search engines also applied in this research include DataStream database that provided by UNIMAS, sampled firm's official website, textbook and journals.

\section{Measurement of Variables \\ Dependent Variable}

In this investigation, the capital structure was the index for dependent variable and debt ratio as the indicator. Other researchers used the total debt divided with the sum of total equity and total debt to calculate debt ratio (Abor, 2007; Achchuthan et al., 2013; Kajananthan, 2012; Siromi \& Chandrapala, 2017).

\section{Independent Variables}

There are five independent variables of Corporate Governance used in the regression model. First, the measurement for board gender is the proportion of women director on the board. Second, the size of the board was calculated using the logarithm of on board number of directors. Third, the independence of the board represented the proportion of independent non-executive directors on board, and was calculated as the number of independent non-executive directors divided by the number of directors. Fourth, management shareholdings were measured as a percent of shares held by executives or board members disclosed in Annual Reports. Lastly, the measurement for audit independence is using the ratio of the independent members with total members.

\section{Control Variables}

There were two controlled variables to control the firm-specific determinants that will impact the financing decision (Kumar, 2015). One of the controlled variables was size of firm where logarithm total assets used to monitor the economics of scales effect (Siromi and Chandrapala, 2017; Wang and Kuo, 2008; Purag et al, 2016; Shafana, 2016; Hafez, 2017, Abor, 2007). Besides that, another variable was profitability, Return on Assets (ROA) was the indicator of profitability and calculated by dividing the net profit of the company to its total assets to control the firm performance (Vakilifard et al., 2011; Sheikh and Wang, 2012; Purag et al, 2016).

\section{Results and Discussion}

This study employed Descriptive Analysis, Correlation Analysis and Fixed Effects Regression Model to examine the influences Corporate Governance practices on capital structure decisions of 100 top companies for overall Corporate Governance and performance in Malaysian Capital Market over the period 2012 to 2016.

\section{Descriptive Analysis}

Table 1 shows that descriptive analysing of all selected components of total 61 companies listed in Bursa Malaysia from period 2012 to 2016 year. Debt-to-equity mean is 1.0716, means that nearly equivalent amount of debt and equity was used to fund the business assets among non-financial listed corporates. The range for values of DE are 14.3601 and 0.0634 respectively with having 1.3872 of standard deviation. 
INTERNATIONAL JOURNAL OF ACADEMIC RESEARCH IN BUSINESS AND SOCIAL SCIENCES

Vol. 11, No. 14, Contemporary Business and Humanities Landscape Towards Sustainability. 2021, E-ISSN: 2222-6990 @ 2021 HRMARS

\begin{tabular}{|l|l|c|c|c|c}
\hline \multicolumn{1}{|c|}{ Variables } & Mean & Maximum & Minimum & Std. Dev. & Observation \\
\hline Debt-to Equity (DE) & 1.0716 & 14.3601 & 0.0634 & 1.3872 & 305 \\
Board Gender (BG) & 0.1439 & 0.4286 & 0 & 0.1141 & 305 \\
Board Independence (BI) & 0.4811 & 0.8333 & 0.2308 & 0.1253 & 305 \\
Board Size (BS) & 8.2787 & 16 & 4 & 2.0958 & 305 \\
Management Ownership (MG) & 0.0651 & 0.6305 & 0 & 0.1431 & 305 \\
Independence Audit Committee (AC) & 0.88 & 1 & 0.5 & 0.1427 & 305 \\
Firm Size (FS) & 6.1584 & 7.5704 & 4.6826 & 0.6717 & 305 \\
Profitability (ROA) & 0.098 & 0.472 & -0.1396 & 0.0856 & 305 \\
\hline
\end{tabular}

Table 1: Descriptive Analysis

The first Corporate Governance attribute which is the board gender (BG), its maximum and minimum values are 0.4286 and 0 , indicating the maximum number of female directors will be up to almost half proportion of the board size whereas no female directors at all in certain firms with the standard deviation of 0.1141 . Its mean value is 0.1439 which is quite similar to Jaradat (2015). According to the Securities Commissions (2017) identified that the new MCCG 2017 highlights the Large companies need to impose about not less than $30 \%$ of women directors and also promotes participation of women in senior management. Hence, it can be said that there is an improvement for most of companies has increased their female directors to at least 1 to 3 persons. The second proxy of the Corporate Governance variable is the board independence (BI) finds that $48 \%$ of the selected listed companies have significant existence of independent non-executive of directors, indicating a good presentation during the observation. The range for board independence is from 0.2308 to 0.8333 . It agreed with the MCCG which asserted that the non-executive directors in listed firms needed to include no less than $1 / 3$ at the board. This outcome is similar with Siromi and Chandrapala (2017). The result shows the proxy of board size (BS) has an average 8 members of board of directors. Such result has supported by Zabri et al (2016); Shafana (2016), Hassan and Butt (2009); Siromi and Chandrapala (2017) This is consistent with the guidelines and recommendations from Corporate Governance Blueprint 2011, in which the optimal board size of the firm is from 6 to 7 members. Also, the optimum size for board should be 7 to 9 members and 8 members respectively ( Jensen, 1993; Lipton and Lorsch, 1992). For board directors the highest and lowest number is 16 and 4 members respectively with a standard deviation of 2.0958. Next, the mean value managerial ownership (MG) is about $6.5 \%$ which shows a low rate of shareholding among the directors, its maximum value is $63.06 \%$ while the minimum value is $0 \%$ as well as the as 0.1431 of standard deviation. This indicates that among the sample Top 100 listed companies for overall performance of Corporate Governance in Malaysia, some of firm's directors are holding large quantity of share equity in their own company but most of them are holding less shares, even no shareholding in the firm at all. The listed firms in Sri Lanka and Ghana also showed low rate of managerial shareholding which only 3.26\% and 9\% respectively (Agyei and Owusu, 2014; Siromi and Chandrapala, 2017). Independence of audit committees (AC) is distributed with the mean of 0.88 and the result shows most of the firms have comprise largely independent of audit committees which has align the recommendation and principals of MCCG with the standard deviation of 0.1427 . This means that around 3 from 4 members of audit committee are independent members. Uzun et al (2004) found that the higher audit committee independence has resulted in a lower chance of fraud. Majority 
of companies in the sample have high numbers of audit committee members from independence. This outcome closely matches with Arslan et al., (2014) findings and Muazeib et al., (2015) which concluded $91 \%$ and $74 \%$ proportion of independence audit committee. For the controlled variables, the average rate of return is $9.8 \%$. It can be range from -0.1396 to 0.4720 and standard deviation among the Malaysian listed companies are 0.0856 . Such high mean value asserts that most of the firms are well manage the firm's assets in generating the return to the shareholders. Additionally, the corporate average size is 6,1584 as determined by the logarithm of its total assets. The value for the minimum is 4.6826 and maximum is 7.5704 which is within standard deviation of 0.6717. Overall, it can be said that majority of listed firms in Top 100 listed companies for overall performance of Corporate Governance in Malaysia have comply the principles and recommendations of MCCG. Hence, then ranking made by Minority Shareholder Watchdog Group (MSWG) is quite relevant and most all the sample firms are satisfied the Code of Best Practices on Corporate Governance. As evidences, it indicates most of the firms on the ranking have increased the female directors among the board, their independent non-executive directors have at least $1 / 3$ or $2 / 3$ of total directors as well as the optimum board size at 8 members.

\section{Correlation Analysis}

Table 2 shows the debt-to-equity ratio has a coefficient 0.1201 , in which statistically negative relationship with board independence. This result similar with Uwuigbe (2014), large number independent non-executive directors will use less leverage. The correlation coefficient for managerial ownership is -0.1347 and independence of audit committee is -0.2135 as it relates to debt to equity ratio and statistically significant. It can therefore be said, increase in board independence, managerial ownership and independence audit committee will decrease the leverage, it has well aligned the agency theory. While debt to equity is positively correlated with firm's size and return on assets. Board gender and board size, however, do not impact on financial leverage.

\begin{tabular}{|l|cccccccc|}
\hline Variables & DE & BG & BI & BS & MG & AC & ROA & FS \\
\hline DE & 1 & & & & & & & \\
BG & -0.0382 & 1 & & & & & & \\
BI & $-0.1201 * *$ & 0.02615 & 1 & & & & & \\
BS & 0.0194 & -0.0421 & $-0.3707^{* * *}$ & 1 & & & & \\
MG & $-0.1347^{* *}$ & $-0.1542^{* * * *}$ & $-0.1726^{* * *}$ & $-.01753^{* * *}$ & 1 & & \\
AC & $-0.2135^{* * * *}$ & $-0.0945^{*}$ & $0.1770^{* * *}$ & $-0.0993^{*}$ & $0.1295^{* *}$ & 1 & & \\
ROA & $0.1328^{* *}$ & $-0.1368^{* *}$ & $0.1496^{* * *}$ & $-0.1993^{* * *}$ & 0.0175 & -0.0927 & 1 & \\
FS & $0.1778^{* * *}$ & 0.0867 & $-0.1078^{*}$ & $0.3685^{* * *}$ & $-0.2571^{* * *}$ & $-0.2635^{* * * *}$ & $-0.2577^{* * *}$ & 1 \\
\hline
\end{tabular}

Notes: ${ }^{* * *},{ }^{* *}$ and ${ }^{*}$ denote statistically significant at $1 \%, 5 \%, 10 \%$ level respectively.

Table 2: Correlation Analysis

Furthermore, board gender reveals statistically negative associated with managerial ownership, independence of audit committee, and return on assets while zero relationship with board independence, board size and firm size. As far as board independence is concerned, it has a major reverse relationship with board size, managerial ownership and firms size though positively associated with audit committee independence and return on assets. The outcome also verifies board size 
adversely affects managerial ownership, audit committee independence and return on assets. In contrary, only the size of the board has a major positive relation to the size of the company, indicating that large businesses appear to have high number of boards. Managerial ownership is positive associated with the independence of audit committee but negative linkage to firm size as well as insignificant correlation with return on assets. For the independence of audit committee, it shows zero relationship with return on assets but negative relationship with firm size, indicating large firm tend to have less audit committee from independence. Lastly, the finding of the correlation coefficient for return on assets is 0.2577 significant related to firm size negatively.

\section{Breusch-Pagan (BP) Lagrange Multiplier Test}

The section of selection model was mainly used the E-view software to find out the best and suitable model to carry out the regression analysis and hypothesis testing. The first selection step is through the Breusch-Pagan Lagrange Multiplier (BPLM) test to determine whether the corresponding model is the Pooled OLS Model (POLSM) or the Random Effect Model (REM).

\begin{tabular}{|l|c|c|c|}
\hline & \multicolumn{3}{|c|}{ Test hypothesis } \\
\hline & Cross-section & Time & Both \\
\hline Breusch-Pagan & 314.3383 & 1.4866 & 315.8249 \\
& $(0.0000)$ & $(0.2227)$ & $(0.0000)^{* * *}$ \\
\hline
\end{tabular}

Notes: *** denote statistically significant at $1 \%$ level

Table 3: Breusch-Pagan Lagrange Multiplier (BPLM) Test

The above Table 3 shows that the p-value of BPLM test is less than 0.05 significant, suggesting the rejection of the null hypothesis and random effect model is the suitable panel regression model as compare to pooled OLS regression model.

\section{Hausman Test}

After that, another test named Hausman test need to be carried out if the random effect model has been selected. This Hausman test is to select either Random Effect Model (REM) and Fixed Effect Model (FEM) is the best model.

\begin{tabular}{|l|c|c|c|}
\hline Model & Test statistic $\left(\mathbf{C h i}^{2}\right)$ & d.f. & Prob. \\
\hline $\mathrm{DE}$ & 31.3663 & 7 & $0.0001^{* * *}$ \\
\hline
\end{tabular}

Notes: $* * *$ denote statistically significant at $1 \%$ level

Table 4: Hausman test

Table 4 shows the p-value is below 0.05 significant level. Thus, null hypothesis is not supported and FEM will be chosen as compared to REM. Therefore, the final model chosen is the Fixed Effect Model to undergo the regression analysis.

Diagnostic Tests

Before running the regression analysis, multicollinearity and autocorrelation test will be carried 
out to provide more reliable and relevant results (Shafana, 2016; Chitiavi et al., 2013, Wellalage \& Locke, 2012; Uwuigbe, 2014; Achchuthan et al., 2013; Jaradat, 2015; Hafez, 2017; Vakilifard et al., 2011; Kajananthan, 2012).

\begin{tabular}{|c|c|c|c}
\hline Variable & VIF & Tolerance & Durbin Watson \\
\hline BG & 1.07 & 0.9382 & 1.8539 \\
BI & 1.31 & 0.765 & \\
BS & 1.4 & 0.7131 & \\
MO & 1.2 & 0.8347 & \\
AC & 1.17 & 0.8544 & \\
ROA & 1.16 & 0.8585 & \\
FS & 1.36 & 0.734 & \\
\hline Mean & \multicolumn{2}{|c}{1.24} \\
\hline
\end{tabular}

Table 5: Diagnostic Tests

To check for the multicollinearity problem, few tests will be applied in this study which are the variance inflation factor (VIF) and tolerance test. These types of tests are used to investigate that existence of multicollinearity for all variables selected in this study. If the tolerance factor is close to zero or the VIF value is greater than 5 will having a high degree of collinearity of that variable with the other explanatory variables (Shafana, 2016). Using Stata, the result shows that the regression model is free from the question of multicollinearity problems among all VIFs of explanatory variables, including controlled variables, which are less than the value of 5. Also, the autocorrelation problem can be detected through the Durbin Watson test. According to the rule of thumb, the model will be free from the autocorrelation problem in case of the Durbin Watson values are less than 3 (Chitiavi et al., 2013). Since the result has present 1.8539 , means no autocorrelation problem in this panel regression model. Hence, based on the above Table 5, this study can be continued to perform and examine the impact of the Corporate Governance practices and capital structure for top 100 firms from Malaysian Capital Market.

\section{Regression Analysis of Fixed Effect Model}

This analysis is used to examine the relationship between Corporate Governance and decisionmaking on capital structure.

The summary of the regression model is shown in Table 6. 
INTERNATIONAL JOURNAL OF ACADEMIC RESEARCH IN BUSINESS AND SOCIAL SCIENCES

Vol. 11, No. 14, Contemporary Business and Humanities Landscape Towards Sustainability. 2021, E-ISSN: 2222-6990 @ 2021 HRMARS

\begin{tabular}{|l|c|c|c|}
\hline \multicolumn{1}{|c|}{ Variable } & Coefficient & t-statistics & Probability \\
\hline BG & -2.6931 & -4.422 & $0.0000 * * *$ \\
BI & 0.5562 & 0.9582 & 0.339 \\
BS & 0.036 & 0.7866 & 0.4323 \\
MG & 4.8212 & 2.5047 & $0.0129 * *$ \\
AC & -0.9638 & -2.1021 & $0.0366 * *$ \\
ROA & -5.9251 & -6.2914 & $0.0000^{* * *}$ \\
FS & 0.5562 & 1.8703 & $0.0627 * *$ \\
Constant & -1.4171 & -0.7403 & 0.4598 \\
R-squared & 0.8628 & & \\
Adjusted R-squared & 0.824 & & \\
F-statistic & 22.2365 & & \\
P-value (F- statistic) & 0.00000 & & \\
\hline
\end{tabular}

Notes: $* * *, * *$ and $*$ denote statistically significant at $1 \%, 5 \%, 10 \%$ level respectively. Table 6: Regression Analysis of Fixed Effect Model

Therefore, the model equation can be summarized as follows:

$\mathrm{DE}=-1.4171-2.6931 \mathrm{BG}+0.5562 \mathrm{BI}+0.036 \mathrm{BS}+4.8212 \mathrm{AC}-5.9251 \mathrm{ROA}+0.5562 \mathrm{FS}$

Based on the findings, the slope of coefficient of 2.6931 implies if there is an increase of 1 unit in gender, there will be a decrease of 2.6931 units in debt-to-equity, while other variables will remain constant. It indicates a negative relation between board gender with capital structure. there is an increase of 1 unit in the independence of the board, there will be an increase of 0,5562 unit in the debt-to - equity ratio, while other variables will remain constant. They are both positively correlated with each other. In addition, 1 unit increase in board size will increase 0.036 unit of debt-to-equity ratio simultaneously, holding other variables constant. Hence, board size is positively correlated with debt-to- equity. While managerial ownership increase in 1 unit will increase 4.8212 unit in debt-to-equity ratio, holding other variables constant. They are having positive correlation. When the independence of audit committee increases in 1 unit, the debt-toequity decrease to 0.9638 unit, holding other variables will remain constant. They are both showing negative correlation. Nevertheless, when all explanatory variables are held constant, the debtto-equity decrease by 1.4171. For the R-squared, the result of the overall goodness-of-fit test implies that $86.28 \%$ of total variation in debt-to-equity can be clarified by the changed in the Corporate Governance variables (BG, BI, BS, AC and MG) along with the controlled variables (ROA and FS). The remaining $17.6 \%$ distributed to the factors included the error terms. The F-statistics show a 0.0001 p-value which means the impact of Corporate Governance mechanisms are significantly correlated with the financing decision in Malaysian Capital Market. However, in the prior studies, they have provided no consensus result (Shafna, 2016). The R-squared in the studies of Siromi and Chandrapala (2017) and Jaradat (2015) found only $6.5 \%$ and $20.8 \%$ variation of the capital structure can be explained by the Corporate Governance characteristics among nonfinancial Sri Lanka's listed companies from year 2009 to 2013. However, the studies by Adegbile (2015) and Jaradat (2015), providing their R-squared which are $82.5 \%$ and $76.4 \%$ respectively, similar with the result of this research of having the high R-squared.

Five hypotheses are generated based on the previous studies and the discussion based on the 
hypotheses established in this study is as follows:

\section{$H_{1}$ : There is a significant relationship between board gender and the capital structure.}

The empirical finding shows that the board's gender has a negative debt-to - equity relationship and is statistically relevant at $1 \%$. The regression is driven by the first hypothesis and such result is contrary with the findings of Jaradat (2015). It can be proved that diversity of board gender has significant effect on any decision making of firm such as strategic decision, management decision as well as financing decision. Most of the researchers discovered that variety of board not only can improve the efficiency of the work but also increase the overall performance of the firm (Carter et al., 2003; Jaradat, 2015). Again, Rovers (2013) stated that the company will not work well without presence of women directors. Therefore, the result has aligned with prior literature, in which more women directors will control the debt level effectively whilst well manage the firm performance.

\section{$\mathrm{H}_{2}$ : There is a significant relationship between board independence and the capital structure.}

The results of second hypotheses are that board independence is linked positively to the decision on capital structure. The positive correlation has aligned with the agency theory. Kajananthan (2012) demonstrated that supervisory performance of board independence director highly reduces the conflict between shareholders and companies' directors. Therefore, corporates were being controlled effectively will create higher creditworthiness of firm, result more debt can be borrowed. Nonetheless, the finding from the study show no significant effect about the relationship. Bokpin and Arko (2009); Vakilifard et al., (2011) displayed the board independence has zero relationship on capital structure decision of the corporates. Hassan and Butt (2009) and Hamid et al., (2011) also discovered no significant connection. Achchuthan et al., (2013) and Zabri et al., (2016) concluded that no connection existed between board independence and total debt. It means that the advises and supervision of outside directors will not affect the manager when making the firm's decision on capital structure.

\section{$H_{3}$ : There is a significant relationship between board size and the capital structure.}

Based on the result from the regression analysis of Fixed Effect Model, the empirical result demonstrated no connection between board size variable and capital structure variable. Therefore, the following hypothesis has been rejected which stated that there is a significant interaction between board size and capital structure. This result proved that there is insignificant relationship between them. This also compatible with the result by Wellalage and Locke, Hussainey and Aljifri (2012) and Kumar (2005), indicating number of boards has not much effect on the financing decision whether debt or equity financing. Hafez 's findings (2017) provided the similar result that the board size was insignificantly correlated with short-term debt financing, long-term debt financing and total debt financing. 
INTERNATIONAL JOURNAL OF ACADEMIC RESEARCH IN BUSINESS AND SOCIAL SCIENCES

Vol. 11, No. 14, Contemporary Business and Humanities Landscape Towards Sustainability. 2021, E-ISSN: 2222-6990 @ 2021 HRMARS

\section{$H_{4}$ : There is a significant relationship between managerial ownership and the capital structure.}

The findings for the fourth hypotheses reveals that $p$-value for managerial ownership is 0.0129 and the coefficient is 4.8212 . There is therefore a positive correlation on both managerial ownership and leverage at a confidence level of $95 \%$. This result is well matched with the correlation result as well as the hypotheses formulated. Managerial ownership significantly influences financing decision positively which is similar with Corporate Governance philosophy according to Agyei and Owusu (2014). Wellalage and Locke (2012) also verified the positive outcome. They defined that the issue of moral hazard problem, asymmetric information as well as managerial entrenchment will be reduced as higher managerial ownership. This circumstance provides that high managerial shareholding will increase the borrowings of firm. According to Jensen (1986), he noted that the increase of managerial shareholding will decrease the conflict between manager and shareholders even lead to the increase of borrowings. The positive linkage has aligned the agency theory and the active monitoring hypothesis. The higher shareholding will give the managers higher incentives and ability of management. Again, the high controlling

\section{$\mathrm{H}_{5}$ : There is a significant relationship between the independence of audit committee and the capital structure.}

interest will induce them to well managed the debt financing Agyei and Owusu (2014).

In the last findings for the fifth hypotheses explores that the p-value of independence of audit committee shows 0.0366 and statistically significant at $95 \%$ of confidence level. Consequently, an inverse correlation exists between both variables, the independence of audit committee and the capital structure. As a result, such finding has consistent with the fifth hypotheses. This also compatible with the negative finding by Muazeib et al., (2015). Arslan et al., (2014) and Muazeib et al., (2015) which provided that the independent of audit committee will result lower cost of debt. An effective audit committee will attempt to reduce these illegal acts and incentive issues which reinforce the quality and reputation of annual audited financial statements, protect and safeguard shareholder interests. The higher audit committee independence has result lower chance of frauds (Muzeib, 2015). Therefore, they found that higher independence of audit committee plays crucial role to improve performance of companies.

\section{Conclusion}

Overall, the Top 100 listed companies for overall Corporate Governance and performance in Malaysia have pursued high debt policy with low proportion of female directors, high managerial shareholding as well as low percentage of independent audit committees during the observation over the period 2012 to 2016. The theories proposed are well aligned with the Corporate Governance practices and decisions on capital structure. It can be concluded form the findings that the $\mathrm{H} 1, \mathrm{H} 4$, and $\mathrm{H} 5$ have been accepted and $\mathrm{H} 2$ and $\mathrm{H} 3$ are rejected. For the controlled variables, ROA has negative linkage to debt-to-equity, means higher profitability of firm will utilize less debt. In line with the pecking order theory, where a company with higher profits tends to use internal financing, such as retained earnings, rather than relying on debt financing to finance a business project or expansion, borrowing debt is the next option before equity financing. Jaradat 
(2015), Hassan and Butt (2009), Siromi and Chandrapala (2017) found also found negative and significant linkage with the leverage. A further controlled size of the firm is positively linked to the financing decision at a 10 \% level of relevance. This is supported by Jaradat (2015); Sharma (2014) and Vakilifard et al., (2011) which show the positive relation, indicating large corporates will use more debt as they are unlikely to face the probability of default as compare to the small companies. Hafez (2017) also shows the same result. This outcome is supported by the trade-off theory.

\section{Recommendation}

The sample size should be increased to the whole Malaysian market, as well as the observation period, in order to achieve a more substantial and consistent result for the entire population of the listed Malaysian companies. The study was limited to few Corporate Governance characteristics only which are the board gender (BG), board independence (BI), board size (BS), managerial ownership structure (MG) and independence of audit committee (AC). It should consider some other variables such as CEO tenure, board meeting, external auditor, education, and other relevant factors for further study since the result has found the positive interaction between managerial ownership and capital structure decision. Furthermore, this paper does not separate the data from sector to sector. Future study could include financial institutions and banking sectors like insurance company, bank and other all related financial institutional firms. Other than that, due to the enactment of new regulations and rules of the Corporate Governance system and other circumstances. The Corporate Governance mechanisms for decision-making on the financing should be reviewed periodically and find out more potential variables for further study.

\section{References}

Abor, J. (2007). Corporate Governance and financing decisions of Ghanaian listed firms. The International Journal of Business in Society, 7(1), 83-92.

Achchuthan, S., Kajananthan, R., \& Sivathaasan, N. (2013). Corporate Governance practices and capital structure: A case in Sri Lanka. International Journal of Business and Management, 8(21), 114-125.

Adegbile, S. A. (2015). Corporate Governance attributes and capital structure of listed firms in the Nigerian food and beverages industry. International Journal of Public Administration and Management Research, 3(1), 48-56.

Agyei, A., \& Owusu, A. R. (2014). The effect of ownership structure and Corporate Governance on capital structure of Ghanaian listed manufacturing companies. International Journal of Academic Research in Accounting, Finance and Management Sciences, 4(1), 109-118.

Ali, R. A., \& Ahmed, A. (2015). Corporate Governance and capital structure: Empirical evidence from textile weaving companies of Pakistan. South Asian Journal of Banking and Social Sciences, 1(1), 60-73.

Arslan, M., Zaman, R., Malik, R. K., \& Mehmood, A. (2014). Impact of CEO duality and audit committee on firm performance: A study of oil \& gas listed forms of Pakistan. Research Journal of Finance and Accounting, 5(17), 151156.

Berger, P. G., Ofek, E., \& Yermack, D. L. (1997). Managerial entrenchment and capital structure decision. The Journal of Finance, 52(4), 1411-1438. 
Bhatt, P. R. (2016). Corporate Governance in Malaysia: has MCCG made a difference. International Journal of Law and Management, 58(4), 403-415.

Bokpin, G. A., \& Arko, A. C. (2009). Ownership structure, Corporate Governance and capital structure decisions of firms: Empirical evidence from Ghana. Studies in Economics and Finance, 26(4), 246-256.

Brealey, R. A., Myers, S. C., \& Allen, F. (2014). Principles of corporate finance. New York, NY: McGrawHill Education.

Bursa Malaysia Berhad. (2017). Retrieved from: http://www.bursamalaysia.com/market

Cadbury, A. (1992). Report of the committee on the financial aspects of Corporate Governance. London: Gee Professional Publishing Ltd.

Carter, D. A., Simkins, B. J., \& Simpson, W. G. (2003). Corporate Governance, board diversity, and firm value. The Financial Review, 38(1), 33-53.

Chen, L. J., Jung, C., \& Chen, S. Y. (2011). How the pecking-order theory explain capital structure. The Journal of International Management Studies, 6(2), 92- 100.

Chitiavi, M. S., Musiega, M.G., Alala, O. B., Douglas, M., \& Christopher, M. O. (2013). Capital structure and Corporate Governance practices: Evidence from listed non-financial firms on Nairobi Securities Exchange Kenya. IOSR Journal of Business and Management, 10(2), 8-16.

Deloitte Touche Tohmatsu India. (2015). Global trends in Corporate Governance. Retrieved from: https://www2.deloitte.com/content/dam/Deloitte/in/Documents/risk/Corporate \%20Governance/in-risk-global-trends-in-corporate-governance-4Dec2015-noexp.pdf

Fama, E. F., \& Jensen, M. C. (1983). Separation of ownership and control. Journal of Law and Economics, 26(2), 301-325.

Fama, E. F., French, K. R. (2002). Testing trade-off and pecking order predictions about dividends and debt. The Review of Financial Studies, 15(1), 1-33.

Farooq, U., Nazir, M. S., \& Nawaz, M. M. (2012). Operating or financial distress? How much costly they are? American Journal of Scientific Research, 55(3), 96-108.

Ghazouani, T. (2013). The capital structure through the trade-off theory: Evidence from Tunisian firm. International Journal of Economics and Financial Issues, 3(3), 625-636.

Gill, A., Biger, N., Mand, H. S., \& Shah, C. (2012). Corporate Governance and capital structure of small business service firms in India. International Journal of Economics and Finance, 4(8), 83-92.

Gujarati, D. N., \& Porter, D. C. (2009). Basic Econometrics: McGraw-Hill International Edition (5th edition). New York, NY: McGraw-Hill Education.

Hafez, H. M. (2017). Corporate Governance practices and firm's capital structure decisions: An empirical evidence of an emerging economy. Accounting and Finance Research, 6(4), 115-129.

Heng, T. B., Azrbaijani, S., \& San, O. T. (2012). Board of Directors and capital structure: Evidence from leading Malaysian companies. Asian Social Science, 8(3), 123-136.

Hussain, M., Hassan, S., \& Akmal, M. (2016). Effect of profitability and financial leverage on capital structure in Pakistan textile firms. Arabian Journal of Business and Management Review, 6(3), 1-4.

Hussainey, K., \& Aljifri, K. (2012). Corporate Governance mechanism and capital structure in UAE. Journal of Applied Accounting Research, 13(2), 145-160.

Hussin, N., \& Othman, R. (2012). Code of Corporate Governance and firm performance. British Journal of Economics, Finance and Management Sciences, 6(2), 1-22. 
Jaradat, M. S. (2015). Corporate Governance practices and capital structure: A study with special reference to board size, board gender, outside director and CEO duality. International Journal of Economics, Commerce and Management, 3(5), 264-273.

Jensen, M. C. (1993). The modern industrial revolution, exit, and the failure of internal control systems. The Journal of Finance, 48(3), 831-880.

Jensen, M. C., Meckling, W. H. (1976). Theory of the firm: Managerial behaviour, agency costs and ownership structure. Journal of Financial Economics, 3(4), 305-360.

Jensen, M. C. (1986). Agency costs of free cash flow, corporate finance, and takeovers. The American economic review, 76(2), 323-329.

Kajananthan, R. (2012). Effect of Corporate Governance on capital structure: Case of the Sri Lanka listed manufacturing companies. Journal of Arts, Science \& Commerce, 3(4), 63-71.

Karadeniz, E., Kandır, S. Y., Iskenderoglu, O., \& Onal, Y. B. (2011). Firm size and capital structure decisions: Evidence from Turkish lodging companies. International Journal of Economics and Financial Issues, 1(1), 1-11.

Kraus, A., \& Litzenberger, R. H. (1973). A state-preference model of optimal financial leverage. The Journal of Finance, 28(4), 911-922.

Lipton, M., \& Lorsch, J. W. (1992). A modest proposal for improved Corporate Governance. The Business Lawyer, 59-77.

Magdalena, R. (2012). Influence of Corporate Governance on capital structure decision: Evidence from Indonesian capital market. World Review of Business Research, 2(4), 37-49.

Minority Shareholder Watchdog Group. (2016). Annual report 2016: AdvocatingCorporate Governance.

Modigliani, F., \& Miller, M. H. (1958). The cost of capital, corporation finance and the theory of investment. American Economic Review, 48(3), 261-297.

Modugu, K. P. (2013). Capital structure decision: An overview. Journal of Finance and Bank Management, 1(1), 14-27.

Mostafa, H. T., \& Boregowda, S. (2014). A brief review of capital structure theories. Research Journal of Recent Sciences, 3(10), 113-118.

Muazeib, A. I., Chairiri, A., \& Ghozali, I. (2015). Does Corporate Governance drive capital structure of Johannesburg listed companies? International Journal of Business, Economics and Law, 6(1), 23-34.

Myers, S. C. (1984). The capital structure puzzle. The Journal of Finance, 39(3), 575-592.

Myers, S. C. (2001). Capital structure. The Journal of Economic Perspectives, 15(2), 81-102.

Myers, S. C., \& Majluf, N. S. (1984). Corporate financing and investment decisions when firms have information that investors do not have. Journal of financial economics, 13(2), 187-221.

Norwani, N. M., Mohamad, Z. Z., \& Chek, I. T. (2011). Corporate Governance failure and its impact on financial reporting within selected companies. International Journal of Business and Social Science, 2(21), 205-213.

Okiro, K., Aduda, J., \& Omoro, N. (2015). The effect of Corporate Governance and capital structure on performance of firms listed at the East African Community Securities Exchange. European Scientific Journal, 11(7), 504533. 
Purag, M. B., Abdullah, A. B., \& Bujang, I. (2016). Corporate Governance and capital structure of Malaysian family-owned companies. Journal of Business and Retail Management Research, 11(1), 18-30.

Rodrigues, S. V., Moura, H. J. D., Santos, D. F. L., Sobreiro, V. A. (2017). Capital structure management differences in Latin American and US firms after 2008 crisis. Journal of Economics, Finance and Administrative Science, 22(42), 51-74.

Rovers, M. (2013). Women on boards and company performance. Journal of Management and Governance, 17(2), 491-509.

Ruan, W., Tian, G., \& Ma, S. (2011). Managerial ownership, capital structure and firm value: Evidence from China's civilian-run firms. Australasian Accounting, Business and Finance Journal, 5(3), 73-92.

Sharma, A. (2014). Stress and Depression in Destitute and Normal Females. International Journal of Academic Research in Psychology, 1(1), 1-7.

Saad, N. M. (2010). Corporate Governance compliance and the effects to capital structure in Malaysia. International Journal of Economics and Finance, 2(1), 105-114.

Securities Commission Malaysia (2012). Malaysian code on Corporate Governance. Retrieved from: http://micg.org.my/upload/file/articles/11/CODE-CG- 2012.pdf

Securities Commission Malaysia (2017). Malaysian code on Corporate Governance. Retrieved from: https://www.sc.com.my/wp- content/uploads/eng/html/cg/mccg2017.pdf

Shafana, N. (2016). Board of directors' characteristics impact on capital structure decisions: Evidence from top 50 turnover non-financial companies listed on the Colombo Stock Exchange. International Journal of Science and Research, 5(10), 79-86.

Singam, K. (2003). Corporate Governance in Malaysia. Bond Law Review. 15(1), 314-344.

Siromi, B., \& Chandrapala, P. (2017). The effect of Corporate Governance on firms' capital structure of listed companies in Sri Lanka. Journal of Competitiveness, 9(2), 19-33.

The, B. H., Azrbaijani, S., \& Ong, T. S. (2012). Board of directors and capital structure: Evidence from leading Malaysian companies. Asian Social Science, 8(3), 123-136.

Uwuigbe, U. (2014). Corporate Governance and capital structure: Evidence from listed firms in Nigeria stock exchange. Journal of Accounting and Management, 4(1), 5-14.

Vakilifard, H. R., Gerayli, M. S., Yanesari, A. M., \& Ma'atoofi, A. R. (2011). Effect of Corporate Governance on capital structure case of the Iranian listed firms. European Journal of Economics, Finance and Administrative Sciences, 35, 165-172.

Wang, L. H., \& Kuo, H. C. (2008). The effects of Corporate Governance on capital structure in Taiwanese corporations after controlling the heterogeneity of industries and firm size. Corporate ownership of control, 6(1), 35-47.

Waworuntu, S. R., Anastasia, K., \& Rusmanto, T. (2014). The effect of Corporate Governance in capital structure in public listed companies in Indonesia. Abstract of Emerging Trends in Scientific Research, 1, 243-258.

Wellalage, N. H., \& Locke, S. (2012). Corporate Governance and capital structure decisions of Sri Lankan listed firms. Global Review of Business and Economic Research, 8 (1), 157-169.

Zabri, S. M., Yusoff, W. F. W., Ramin, A. K., \& Ling, K. S. S. (2016). Corporate Governance practices and firm's capital structure. International Business Management, 10(17), 3973-3981. 
INTERNATIONAL JOURNAL OF ACADEMIC RESEARCH IN BUSINESS AND SOCIAL SCIENCES

Vol. 11, No. 14, Contemporary Business and Humanities Landscape Towards Sustainability. 2021, E-ISSN: 2222-6990 @ 2021 HRMARS

Zikmund, W. G., Babin, B. J., Carr, J. C., \& Griffin, M. (2010). Business research methods (8th edition). South Western: Cengage Learning. 